\title{
Necdet Güner
}

Pamukkale University, nguner@pau.edu.tr, Denizli-Turkey

Zeynep Akkurt Denizli, Renan Sezer, Ayşegül Bayraktar Ankara Üniversitesi, Ankara-Turkey

zeynepoakkurt@gmail.com; renan_sezer@yahoo.com; aysegulfsu@yahoo.com

http://dx.doi.org/10.12739/NWSA.2015.10.2.1C0632

\section{6.-8. SINIF ÖĞRENCİLERİNIN MATEMATİK DERSİ VE MATEMATİK DERS KİTAPLARI HAKKINDAKI GÖRÜŞLERINI BELİRLEMEYE YÖNELIKK ÖLÇEK GELIŞTIRME ÇALIŞMASI}

\section{ÖZET}

Bu çalışmanın amacı, 6.-8. sınıf öğrencilerinin matematik dersi ve ders kitapları hakkında görüşlerini araştırmaya yönelik bir ölçek geliştirmektir. Bu amaçla hazırlanan 47 maddeden oluşan ölçek, pilot uygulamadan sonra 6.-8. sınıfa devam eden 941 öğrenciye uygulanmış ve faktör analizinden sonra 30 maddeye indirgenmiştir. Yapılan faktör analizi, ölçeğin: matematik ders kitapları, matematiksel düşünme düzeyi, matematik dersinde kitap kullanımı, öğretmenin matematik dersini işleyişi ve öğretmenin matematiksel düşünme ve iletişime verdiği önem olmak üzere beş alt faktöre ayrıldığını göstermiştir. Cronbach Alpha değeri 0,852 olarak bulunan ölçeğin geçerli ve güvenilir bir araç olduğu düşünülmektedir.

Anahtar Kelimeler: 6.-8. Sınıf Öğrencileri, Matematik Eğitimi, Matematik Ders Kitapları, Matematik Dersi, Öğrenci Görüşleri, Ölçek Geliştirme

THE DEVELOPMENT OF A SCALE TO DETERMINE 6TH-8TH GRADE STUDENTS' OPINIONS ON THE MATHEMATICS COURSE AND MATHEMATICS TEXTBOOKS

\section{ABSTRACT}

The aim of this study was to develop a scale to evaluate the mathematics courses and textbooks from middle school students' perspective. After completion of the pilot study, 47 items from the initial version of the scale were given to 941 students from grades 6th-8th, and following the factor analysis, the scale was ultimately reduced to 30 items. The factor analysis indicated that this scale consists of five subcategories, namely: mathematics textbooks, level of mathematical thinking, use of textbooks during mathematics classes, pedagogy used by the teacher during mathematics classes, and the importance the teacher gives to mathematical thinking and communication. The scale whose Cronbach Alpha was found to be 0.852 is considered to be both valid and reliable.

Keywords: 6th-8th Grade Students, Mathematics Education, Mathematics Textbooks, Mathematics Course, Students' Opinions, Perspective, Scale Development 
Güner, N., Akkurt Denizli, Z., Sezer, R. ve Bayraktar, A. NWSA-Education Sciences, 1C0632, 10, (2), 54-65.

\section{GIRIŞ (INTRODUCTION)}

Dünyadaki gelişme ve değişimler, toplumların; eleştirel düşünebilen, akıl yürüten, yorum yapabilen, kendi kendine öğrenebilen işbirlikçi yurttaşlara duyduğu gereksinimi arttırmakta, dolayısıyla eğitimin amacı da bu doğrultuda şekillenmektedir. Bu amaca yönelik olarak eğitimde, öğrencinin bilgiyi öğrenirken öncelikle kendisinin keşfetmesi, teknolojiyi etkili kullanması ve grup çalışmaları yapması ön plana çıkmıştır. Bu doğrultuda ülkeler, ders programlarını hem içerik, hem vurgu, hem de uygulanan pedagoji açısından yenilemektedirler. Türkiye'de de Milli Eğitim Bakanlığı Talim Terbiye Kurulu tarafından 6.-8. sınıf matematik programı yenilenmiş ve 20062007 öğretim yılında uygulamaya konulmuştur. Bu programın felsefesini yansıtan ders kitapları da 2006 yılı itibari ile kademeli olarak yazılmış ve sınıflarda kullanılmaya başlanmıştır.

Ülkeler arası matematik başarısının karşılaştırıldığı çalışmalarda, öğrenci başarısını en çok etkileyen faktörün, kullanılan program olduğu saptanmıştır (Cai, 2003; Jackson, 1992). Reys, Lappan ve Hirsch (2003) öğretim programlarını, tasarlanan öğretim programı, ders kitabındaki öğretim programı, uygulanan öğretim programı ve değerlendirilen öğretim programı olmak üzere dört kategoride sınıflandırmışlardır. Öğrenciler için programının yansıması ders kitaplarıdır ve ders kitapları, tasarlanan öğretim programının ne kadar hayata geçirebildiğini ortaya koymakta (Remillard, 2000), dolayısı ile öğretim programını hayata geçirmede bir köprü görevi üstlenmektedir (Li, Chen ve An, 2009). Ders kitapları, ulusal amaçları ortaya koyan ders programlarını yansıtmaktadır (Haggarty ve Pepin, 2002; Schmidt, McKnight ve Raizen, 1997). Ayrıca öğretmenler, ders kitaplarını, içerik olarak otorite addeden (Freeman ve Schmidt, 1982) ve ne öğretilmesi gerektiğini söyleyen bir kılavuz olarak algıladıkları (Talmage, 1972; Barr, 1988) için öğrenme ve öğretim, ders kitaplarının içeriği ve doğası ile doğrudan bağlantılıdır (Tyson ve Woodward, 1989; Tyson ve Bernstein, 1988; Woodward ve Elliott, $1990)$.

Ders kitapları, öğretmene, sınıfta ne öğreteceği, hangi derinlikte öğreteceği, nasıl bir organizasyon yapacağı (Tyson ve Woodward, 1989) ve nasıl öğreteceği konusunda (Fan ve Zhu, 2000) rehberlik etmektedir. Öğretmenlerin matematik öğretimi ve kullandıkları pedagojik yöntemler üzerine yapılan çalışmalar, öğretmenlerin öğretim programlarını anlamalarında ve uygulamalarında ders kitaplarının büyük etkisi olduğunu ortaya koymaktadır (Graybeal, 1988; Krammer, 1985; Sosniak ve Stodolsky, 1993). İçlerinde bulundurdukları etkinlikler ve alıştırmalar ile sınıf içi eğitimi de yapılandıran ders kitapları (Reys, Reys ve Chavez, 2004), öğretmen tarafından sınıfta kullanılan pedagojik yöntemlerin temel kaynağı olarak gösterilmektedir (Apple, 1986). Ders kitapları ayrıca, öğrenci ve veli için öğretim programı ile eş olarak görüldüğünden, reform hareketleri sonucu hazırlanan programın en önemli aracıdır (Valverde, Bianchi, Wolfe, Schmidt, Houang, 2002). Bu açıdan bakıldığında, programla ilgili öğrenci görüşü alınırken ders kitapları hakkında görüş almak da kaçınılmaz olmaktadır.

Ders kitaplarının yanı sıra, sınıf içindeki eğitim, kullanılan pedagoji ve yapılan etkinlikler de öğrenci için programın yansımalarıdır. Öğretmenleri tarafından etkileşimde bulunmaya, matematik materyallerini ve çalışmalarını sözlü olarak ifade etmeye güdülenen öğrencilerin daha fazla öğrenme gerçekleştirdikleri görülmektedir (da Ponte, 2012). Dolayısıyla bir öğretim programının etkili olabilmesi için öğretmenin, öğrencinin ve programın sürekli etkileşim ve işbirliği içinde olması gerekmektedir (Wong, Lam, sun ve 
Güner, N., Akkurt Denizli, Z., Sezer, R. ve Bayraktar, A. NWSA-Education Sciences, 1C0632, 10, (2), 54-65.

\begin{abstract}
Yan Chan, 2008). Öğretim programları, hangi konuların nasıl öğretildiğini ve öğrenildiğini belirlemekte; dolayısıyla, programın uygunluğu ve içeriğinin anlaşılır olması, öğretmenlerin ders planlarına yansımaktadır (Castro Superfine, 2008). Diğer bir deyişle, programın öngördüğü ders kitapları, ders konuları, teknoloji, araçgereçler, öğretmenlerin ders planlarını etkilemektedir (Hirsch ve Reys, 2009). Tüm bunlar göz önünde bulundurulduğunda, programın genel yapısının yanı sıra öğretmenin matematik programını nasıl uyguladığı ve bu uygulamanın öğrenciler tarafından nasıl algılandığı oldukça
\end{abstract} önemli bir olgudur.

Öğrencilerin matematik dersi hakkındaki görüşlerini almaya yönelik yapılan araştırmalar, genellikle öğrenci tutumlarına yer vermiş ve matematiksel düşünme ile matematiğe karşı tutum arasında anlamlı, pozitif yönde ve yüksek düzeyde ilişki bulmuşlardır (Kargar, Tarmizi ve Bayat, 2010; Shiyyab, el-Hersh ve Mufleh, 2010). Araştırmalar, aynı zamanda öğrencilerin matematiğe karşı tutumu ile matematik başarıları arasında pozitif bir korelasyon olduğunu göstermektedir (Aşkar, 1986; Uşun ve Gökçen, 2010; Papanastasiou, 2000). Alanda birçok araştırmacı (Altun ve Arslan, 2006; Aşkar, 1986; Lipnevich, MacCann, Krumm, Burrus ve Roberts, 2011; Turanlı, Karakaş Türker ve Keçeli, 2008; Yenilmez, 2010), matematik dersine yönelik öğrenci tutumlarını incelenmiştir. Bundan dolayı ilgili çalışmada kullanılan ölçekte tutumlara değinilmemiş, kullanılan ders kitaplarına ve öğretmenin düzenlediği etkinliklere odaklanılmıştır; çünkü öğrenci başarısını artırmada, öğrencilerin tutumlarının olumlu olmasına yönelik önlemlerin alınması ve düzenlemelerin yapılmasında öğretmen kilit rol oynamaktadır (Marchis, 2011). Dolayısıyla, matematik programının değerlendirilmesinde, öğretmenin etkisi ve dersi sunuş şekli öncelikle ele alınmıştır.

Türkiye'de 6.-8. sınıf matematik programının uygulamaya geçirilmesinin üzerinden yaklaşık sekiz yıl geçmiştir. Bu süre zarfında, matematik programının uygulanışında yaşanılan zorluklar, program hakkında görüşler, programın felsefesini yansıtan ders ve öğrenci çalışma kitapları ile öğretmen kılavuz kitapları üzerine çeşitli araştırmalar (Demircioğlu, 2009; Soycan, 2006; Yılmaz, 2006) yapılmıştır. Ancak, bu çalışmaların büyük bir çoğunluğu, yüksek lisans tez öğrencilerinin bulunduğu bölgelerdeki kısıtlı olanaklarla ulaşabildikleri, öğretmen, öğrenci, veli, yönetici üzerine yaptıkları çalışmalarla sınırlı kalmıştır. Ülkemizdeki 6.-8. sınıf öğrencilerinin, matematik programı hakkındaki görüşleri, yaşamı öğrenme, matematiği öğrenme, öğrenmeyi öğrenme, iletişim kurmayı öğrenme, değerlendirme, öğrenmede öğretmen desteği ve program değerlendirme olmak üzere yedi alt bölümde incelenmiştir (Soycan, 2006). Ayrıca, yeni kitapların öğrenciler tarafından nasıl değerlendirildiğini araştıran çalışmalar da yapılmıştır (Çakır, 2009; Dayak, 1998; Demircioğlu, 2009; Karakelleoğlu, 2007; Taşdemir, 2009; Yüksel, 2010). Adana il merkezindeki 5. sınıf düzeyindeki 560 öğrenciyle yapılan bir çalışmada, öğrencilerin; matematik ders kitaplarında, alıştırma ve problem sayılarının arttırılmasını istedikleri; daha fazla konu anlatımlarına gereksinim duydukları; görsellere, eğlendirici oyun ve etkinliklere daha fazla yer verilmesini istedikleri ortaya çıkmıştır (Çakır, 2009). Yine Adana il merkezinde, 6. sınıf düzeyindeki 535 öğrenciyle yapılan görüşmelerle, öğrencilerin matematik ders kitabını; baskı, teknik tasarım ve düzenleme, konu anlatımı, örnek ve alıştırma sayısı bakımından kısmen yeterli buldukları sonucuna ulaşılmıştır (Yüksel, 2010). Bitıis ilindeki 6-8. Sınıf düzeyindeki toplam 401 öğrenciyle yapılan araştırmada ise Taşdemir (2009), sınıf düzeyi arttıkça öğrencilerin 
matematiğe yönelik tutum puanlarının azaldığını ve bunun nedenlerinden birinin, öğrenci düzeyine uygun olmayan ders kitapları olabileceğini savunmaktadır. Bal ve Artut (2013), sekiz 6.-8. sınıf matematik öğretmeniyle, 6. sınıf matematik programı uygulamalarına ilişkin derinlemesine görüşmeler yapmışlar ve çalışmada, öğretmenler; matematik programındaki konuların öğrenciler için yeterli ve ilgi çekici olduğunu, ancak ders kitaplarında, bu konuların detaylı bir şekilde yer almadığını, yüzeysel olarak anlatıldığını savunmuşlardır. İlgili araştırmalarda, öğrencilerin, 2006-2007 yılında uygulamaya koyulan matematik programı ile ilgili görüşlerinin sınırlı düzeyde ve yerel olarak incelendiği görülmektedir.

\section{2. ÇALIŞMANIN ÖNEMI (SIGNIFICANCE OF THE RESEARCH)}

Matematik programı; öğretmenler, yöneticiler ve veliler açısından benimsenmiş olabilir; ancak programdan en çok etkilenen grubun, diğer bir deyişle öğrencilerin program hakkındaki görüşleri, programın güçlü ve zayıf yönlerinin saptanması, program geliştiricilere dönüt vermesi açısından önemlidir. Dolayısıyla, matematik programının öğrenci görüşleri doğrultusunda derinlemesine incelenmesinin, daha fazla değişkene bakılmasının, daha fazla sayıda öğrenciyle çalışılmasının, bu programın başarılı ve başarısız yanlarının belirlenmesi ve gerektiğinde yeniden düzenlenmesi konusunda eğitimcilere yol göstereceği düşünülmektedir. Türkiye'de bu amaçla geliştirilmiş bir ölçek bulunmamaktadır. Bu çalışmada geliştirilecek olan ölçekle, bu alandaki önemli bir eksiğin giderileceği düşünülmektedir. Bu çalışmanın amacı, 6.-8. sınıf matematik derslerini, derslerin işlenişini, ders için dağıtılan kitapları ve kullanımlarını, sınıfta düşünme ve iletişime verilen önemi öğrenci görüşüne göre değerlendiren, programın öğrencinin matematiksel düşünme düzeyine etkisini ölçmeyi hedefleyen geçerli ve güvenilir bir ölçek geliştirmektir.

\section{YÖNTEM (METHOD)}

\section{1. Ölçeğin Oluşturulması (Preparation of the Scale)}

6.-8. sınıf öğrencilerinin; matematik dersi, dersin işlenişi ve bu derste kullanılan kitaplar hakkındaki görüşlerini almak için oluşturulan ölçeğin maddelerini belirlenmek üzere, alanyazın taraması ile daha önce yapılmış araştırmalar da incelenerek 60 maddelik bir taslak hazırlanmıştır. Hazırlanan 60 maddelik taslak için üçü matematik eğitimi uzmanı, ikisi ölçme ve değerlendirme uzmanı olmak üzere eğitim bilimleri fakültesinden toplam beş öğretim üyesinin görüşlerine başvurulmuştur. Görüşlerine başvurulan öğretim üyelerinin çoğunluğu, hazırlanan 60 maddeden sekizinin diğer maddeler ile benzerlik gösterdiğini, beşinin ise ölçülmesi istenen konu ile ilgisi olmadığını bildirmişlerdir. Uzman görüşleri ile 13 maddesi elenen taslak ölçeğin kapsam geçerliği sağlanmış ve 47 madde içerecek şekilde yeniden düzenlenmiştir.

Hazırlanan taslak ölçeğe ilk olarak, yapılması planlanan araştırmanın amacının ve uygulanacak aracın içeriğinin öğrencilere kısaca açıklandığı bir bölüm eklenmiştir. Bu bölümde, öğrencilere çalışmaya katılımın gönüllülük esasına dayandığı, bu çalışmaya katılmak istemedikleri takdirde dağıtılan formları doldurmadan iade edebilecekleri belirtilmektedir. Bu kısımda ayrıca, çalışmaya katıldıkları takdirde verecekleri bilgilerin sadece akademik bir çalışmada kullanılacağı, bu bilgilerin hiçbir şekilde üçüncü şahıslarla veya başka kurum ve kuruluşlarla paylaşılmayacă̆ı anlatılmaktadır. İkinci bölümde öğrencilerle ilgili demografik bilgilerin toplanması amacını güden sorulara yer verilmiştir. Bu 
sorular öğrencinin cinsiyeti, öğrenim gördüğü sınıf, okulunun türü (özel /devlet okulu olması) ve anne-babasının eğitim durumları gibi bilgileri içermektedir. Üçüncü bölüm ise geliştirilmekte olan ölçeğe ait 47 maddeden oluşmaktadır. Bu bölümden hemen önce, sorulara yanıt verirken o yıl aldıkları matematik dersini, dersin öğretmenini ve kullandıkları ders kitabını göz önüne almalarını belirten bir uyarı yer almaktadır. Üçüncü bölümde, öğrencilerden, verilen her maddedeki tümceye ne kadar katıldıklarını her madde için verilmiş olan Likert tipi ölçeği işaretleyerek belirlemeleri istenmektedir. Beşli Likert tipi ölçekteki seçenekler: 1- Hiç katılmıyorum, 2- Katılmıyorum, 3Kararsızım, 4- Katılıyorum ve 5- Tamamen katılıyorum olarak verilmiştir.

\subsection{Pilot Uygulama (Pilot Study)}

Hazırlanan ölçek, Ankara Üniversitesi Eğitim Bilimleri Fakültesi'nde yüksek lisans yapan 6.-8. sınıf öğretmenlerinin ders verdikleri Afyon, Ankara, Aydın, Bolu, Çorum, Denizli, Düzce, Gaziantep, Kırıkkale, Van ve Şırnak illerindeki 385 öğrenci üzerinde uygulanarak pilot çalışma yapılmıştır. Pilot çalışmaya katılan öğrencilerden ölçekteki maddelerdeki ifadelerden anlamadıkları bölümleri işaretlemeleri istenmiştir. Pilot çalışma sonunda, öğrencilerin çoğunun anlamadıklarını belirttikleri yedi madde, beş öğretim üyesinin görüşleri de alınarak ölçekten çıkartılmıştır. Pilot uygulama sonucunda ölçek, 40 madde içerir hale getirilmiştir.

\section{3. Ölçeğin Uygulanması (Implementation of The Scale)}

Hazırlanan ölçek, 2011-2012 akademik yılının sonlarında, İstanbul ilindeki; il merkezi, ilçe, belde ve köy okullarından rastgele seçilen 6., 7. ve 8. sınıfa devam eden öğrencilere uygulanmıştır. Rastgele seçilen okulların, ildeki devlet okulları ile özel okulların oranlarını yansıtacak biçimde olmasına dikkat edilmiş, ölçek, 10'u devlet ve ikisi özel olmak üzere toplam 12 okulda uygulanmıştır.

\subsection{Verilerin Analizi (Data Analysis)}

Toplanan veriler, araştırmacılar tarafından teker teker incelenmiştir. Tamamen veya büyük bir bölümü boş bırakılmış olan formlar, değerlendirme dışı bırakılmıştır. Ayrıca, tamamı yanıtlanmış olan; ancak her soru için aynı şıkkın işaretlendiği formlar da değerlendirilmeye alınmamıştır. Bahsedilen eleme işlemlerinden sonra analizler için toplam 941 kullanılabilir formun kaldığı belirlenmiştir. Formlar, 1'den 941'e kadar numaralandırılmış ve veriler bilgisayar ortamına işlenerek gerekli istatistiksel analizler SPSS 16 (Social Science Statistics Programme) kullanılarak yapılmıştır.

\section{BULGULAR (FINDINGS)}

Elde edilen verilerin yapı geçerliliğini test etmek amacıyla öncelikle açımlayıcı ve doğrulayıcı faktör analizleri yapılmıştır. Daha sonra, ölçeği oluşturan her bir faktör ve ölçeğin bütünü için Cronbach Alfa güvenlik katsayıları hesaplanmıştır.

\subsection{Açımlayıcı Faktör Analizi (Factor Analysis)}

Ölçeğin yapı geçerliliğini incelemek amacıyla öncelikle elde edilen verilerin faktör analizi uygulamak için uygun olup olmadığına bakılmıştır. Örneklemin Kaiser Meyer Olkin (KMO) değeri 0,905 bulunmuştur. Bartlett Küresellik testi sonucunda ise $\left(\chi^{2}=10485,487\right.$ ve $\mathrm{p}=0,000)$ istatistiksel olarak anlamlı farklılık olduğu görülmüştür. Bu 
Güner, N., Akkurt Denizli, Z., Sezer, R. ve Bayraktar, A. NWSA-Education Sciences, 1C0632, 10, (2), 54-65.

değerler sonucunda eldeki verilere açımlayıcı faktör analizi
uygulanabileceğine karar verilmiştir (Büyüköztürk, 2010; Kalaycı,
2008; Karasar, 2012).
Daha sonra, ölçeğe ait 40 madde için öz değerler hesaplanmış ve
öz değerlerin grafiği ile faktör sayıs belirlenmiştir. Bu
hesaplamaların sonucu ilk iki öz değer 6,373 ve 3,574 olarak
bulunmuştur (Grafik 1). Grafikte beşinci öz değerden sonraki
değerlerin birbirlerine yakın olması göz önüne alınarak ölçeğin beş
faktörlü hesaplamaları yapllmıştır.

Scree Plot

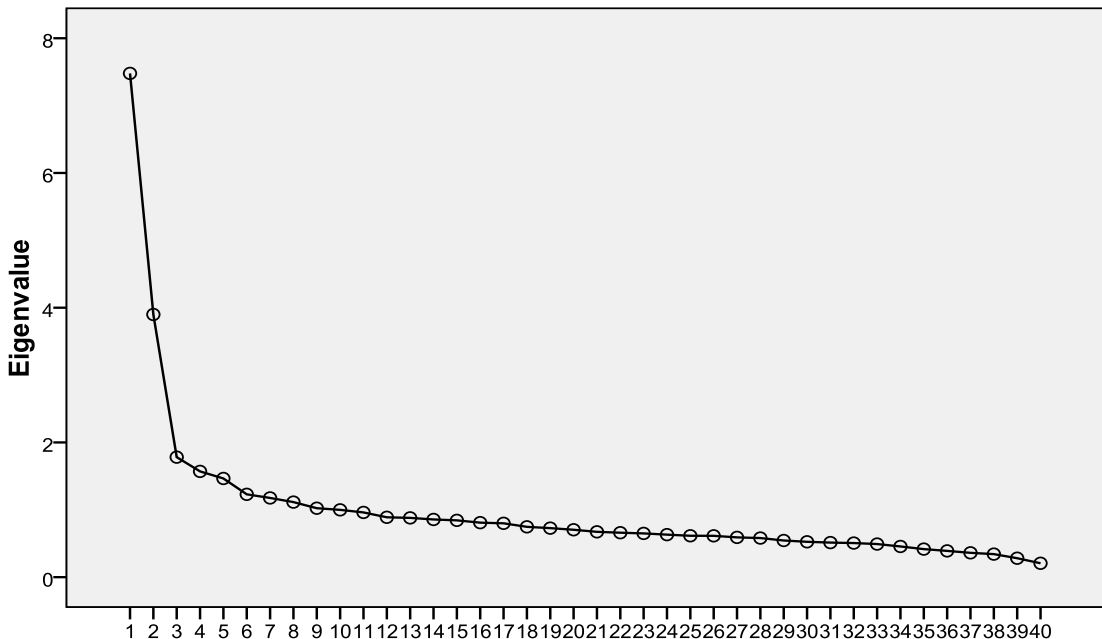

Component Number

Grafik 1. Öz değerler grafiği

(Graph 1. Graph of eigenvalues)

Asal eksenlere göre döndürülmüş (varimax-rotated) temel bileşenler yöntemi kullanılarak yapılan faktör analizi sonunda her bir maddenin faktör yükleri hesaplanmıştır. Bu hesaplamalar sonucu faktör yükleri 0,400'den küçük bulunan "Velim, sınav ve ders notlarımdan bağımsız olarak, matematiği öğrenmeme önem verir.", "Matematik kitabındaki problemlerin tek bir çözüm yolu vardır.", "Öğretmenimiz, konuların anlatımında ders kitabının dışına çıkar.", "Dersten sonra kitabımı okurum." ile "Matematik dersindeki etkinlikler, dersi benim için ilgi çekici hale getirir." ifadelerinin bulunduğu 2, 10, 24, 34 , ve 35. maddeler ölçekten çıkartılmıştır. Ayrıca, madde 7, 15, 16, 21 ve 22'nin faktör yüklerinin, iki veya daha fazla faktörde 0,100'dan daha yakın değerler aldığı görülmüş ve bu maddeler ölçekten çıkarılmıştır (Büyüköztürk, 2010; Kalaycı, 2008). Çıkarılan bu maddeler sırasıyla: (7) "Öğretmenimiz bizim araştırma yapmamızı ister"; (15) "Ders ve çalışma kitaplarının ayrı ayrı olması yararlıdır."; (16) "Ders ve çalışma kitaplarındaki soru sayısı yeterlidir."; (21) "Proje ödevlerimi yaparken büyüklerimden yardım alırım." ve (22) "Öğretmenimiz ders kitabında olmayan etkinlikler de yaptırır." ifadeleridir. Kalan 30 maddenin faktör yükleri, beş faktör altındaki dağılımı, öz değerleri ve açıkladığı varyansları Tablo 1'de verilmektedir. 
Güner, N., Akkurt Denizli, Z., Sezer, R. ve Bayraktar, A. NWSA-Education Sciences, 1C0632, 10, (2), 54-65.

\begin{tabular}{|c|c|c|c|c|c|c|c|c|c|}
\hline \multicolumn{10}{|c|}{ Tablo 1} \\
\hline $\begin{array}{l}\text { Madde } \\
\text { No }\end{array}$ & $\begin{array}{c}1 . \\
\text { Faktör }\end{array}$ & $\begin{array}{c}\text { Madde } \\
\text { No }\end{array}$ & $\begin{array}{c}2 . \\
\text { Faktör }\end{array}$ & $\begin{array}{c}\text { Madde } \\
\text { No }\end{array}$ & $\begin{array}{c}3 . \\
\text { Faktör }\end{array}$ & $\begin{array}{c}\text { Madde } \\
\text { No }\end{array}$ & $\begin{array}{c}4 . \\
\text { Faktör }\end{array}$ & $\begin{array}{c}\text { Madde } \\
\text { No }\end{array}$ & $\begin{array}{c}5 . \\
\text { Faktör }\end{array}$ \\
\hline 5 &, 763 & 37 &, 759 & 33 &, 686 & 9 &, 578 & 29 &, 591 \\
\hline 8 &, 761 & 36 & .723 & 32 &, 654 & 17 &, 531 & 31 & 572 \\
\hline 1 &, 728 & 25 &, 686 & 38 &, 641 & 4 & 521 & 26 &, 539 \\
\hline 14 &, 724 & 19 &, 614 & 40 & 637 & 18 &, 504 & 23 &, 533 \\
\hline 13 &, 701 & & & 39 & 616 & 27 &, 453 & 20 &, 523 \\
\hline 12 &, 687 & & & & & 28 &, 436 & 30 &, 438 \\
\hline 11 &, 655 & & & & & & & & \\
\hline 6 &, 625 & & & & & & & & \\
\hline 3 &, 481 & & & & & & & & \\
\hline $\begin{array}{c}\text { Öz } \\
\text { değer }\end{array}$ & 6,373 & & 3,574 & & 1,613 & & 1,406 & & 1,200 \\
\hline F.A.V. & 21,242 & & 11,913 & & 5,377 & & 4,686 & & 3,999 \\
\hline T.V. & 21,242 & & 33,155 & & 38,532 & & 43,218 & & 47,217 \\
\hline
\end{tabular}

F.A.V: Faktörün açıkladığı varyans, T.V: Toplam varyans.

(F.A.V: Variance explained by the factor, T.V: Total variance)

Her bir faktörün içerdiği maddeler gözden geçirilerek alt faktörler adlandırılmış ve içerdikleri maddelerle birlikte Tablo 2'de listelenmiştir. Bunlar: öğrencinin matematik ders kitapları hakkındaki görüşleri, öğrencinin matematiksel düşünme düzeyi, matematik dersinde kitap kullanımı, matematik dersinin işlenişi ve sınıfta matematiksel düşünme ve iletişime verilen önem, olarak adlandırılmışlardır. Bunun dışında, ölçeği oluşturan 30 maddenin ayırt edicilik düzeylerini belirlemek amacı ile her madde için o27'lik alt ve üst grupların ortalamaları karşılaştırılmıştır. Bu karşılaştırmalar sonucunda elde edilen $t$ değerlerinin 33,571 ile 116,148 arasında olduğu görülmüştür. Alt ve üst $\frac{0}{2} 7^{\prime} l i k$ gruplar arasındaki farklara ilişkin t değerlerinin p<0,001 düzeyinde anlamlı olması her bir maddenin ayırt edici özelliğe sahip olduğunu göstermektedir (Erkuş, 2012).

\subsection{Doğrulayıcı Faktör Analizi (Confirmatory Factor Analysis)}

Açımlayıcı faktör analizinde elde edilen otuz madde beş faktörden oluşan model üzerinde doğrulayıcı faktör analizi yapılarak uyum indeksleri hesaplanmıştır. Yapılan hesaplamalar sonucunda, $\chi^{2}$ $=1259,61(\mathrm{df}=395, \mathrm{p}=0,000)$ değeri elde edilmiştir. $\chi^{2} / \mathrm{df}=3,19$ oranının beşten küçük olması modelin kabul edilebilir bir uyum iyiliğine sahip olduğunu göstermektedir (Şimşek, 2007). Bunun dışında;

RMSEA (Root Mean Square Error of Approximation) 0,048

GFI (Goodness of Fit Index) 0,92

AGFI (Adjusted Goodness Fit Index) 0,90

PGFI (Parsimony Goodness of Fit Index) 0,78

CFI (Comparative Fit Index) 0,90

IFI (Incremental Fit Index) 0,90

NFI (Normed Fit Index) 0,85

NNFI (Non-Normed Fit Index) 0,89 olarak hesaplanmıştır.

Oluşturulan modelin RMSEA ve AGFI değerleri mükemmel, diğer değerlerin ise kabul edilebilir düzeyde olduğu görülmektedir (Kline, 2011; Tabachnick ve Fidell, 2012). 
Güner, N., Akkurt Denizli, Z., Sezer, R. ve Bayraktar, A. NWSA-Education Sciences, 1C0632, 10, (2), 54-65.

\section{3. Ölçeğin Güvenirliği (Reliability of the Scale)}

Ölçeğin 30 maddesinin Cronbach Alfa katsayısı hesaplanmış ve 0,852 olarak bulunmuştur. Ayrıca ölçeğin her bir faktörü için Cronbach Alfa katsayıları da hesaplanmış ve bu değerler sırasıyla: 0,875; 0,737; 0,785; 0,690 ve 0,681 olarak bulunmuştur. Bu sonuç, geliştirilen ölçme aracının, ölçmek istediği özelliğe karşı oldukça duyarlı olduğunu göstermektedir (Kalaycı, 2008).

Tablo 2. Ölçeği oluşturan faktörler ve maddeler.

(Table 2. Factors and items of the scale)

\begin{tabular}{|c|c|c|}
\hline \multirow{10}{*}{ - } & Md. & ğrencinin matematik ders kitapları hakkındaki görüşleri \\
\hline & 5 & Ders kitabındaki etkinlikler, beni matematik öğrenmeye teşvik eder. \\
\hline & 8 & Ders kitabındaki etkinlikler konuyu kavramama yardımcı olur. \\
\hline & 1 & $\begin{array}{l}\text { Kullandığımız matematik kitabı derste anlamadığım konuları öğrenmeme } \\
\text { yardımcı olur. }\end{array}$ \\
\hline & 14 & Ders kitabındaki etkinliklere yönelik açıklamalar net ve anlaşılırdır. \\
\hline & 13 & Ders kitabındaki etkinlikler, bende araştırma yapma isteği uyandırır. \\
\hline & 12 & Ders kitabındaki sayfa düzeni, önemli noktaları görmeme yardımcı olur. \\
\hline & 6 & $\begin{array}{l}\text { Ders ve çalışma kitaplarındaki senaryolar (örnek matematiksel durumlar) } \\
\text { matematiğin hayatla ilişkisini görmeme yardımcı olur. }\end{array}$ \\
\hline & 11 & $\begin{array}{l}\text { Matematik ders kitabındaki her ünitede birden çok öğrenme alanının } \\
\text { bulunması konuya odaklanmamı sağlar. }\end{array}$ \\
\hline & 3 & Proje ödevleri, konu hakkında daha detaylı bilgi edinmemi sağlar. \\
\hline \multirow{5}{*}{ N } & Md. & Öğrencinin matematiksel düşünme düzeyi \\
\hline & 37 & Sınıftaki matematiksel tartışmalara düşünce üreterek katılırım. \\
\hline & 36 & Öğretmenimizin sorduğu "Neden? / Niçin?" sorularını yanıtlayabilirim. \\
\hline & 25 & Derslere matematiksel düşünce boyutunda katılı \\
\hline & 19 & Problem çözme basamaklarını bilirim. \\
\hline \multirow{6}{*}{ 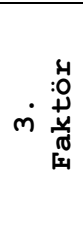 } & Md. & Öğrencinin Matematik dersinde kitap kullanımı \\
\hline & 33 & Öğretmenimiz, sınıfta verdiği örnekleri ders kitabından seçer. \\
\hline & 32 & Öğretmenimiz, ev ödevlerini ders veya çalışma kitabından seçer. \\
\hline & 38 & Verilen ödevleri yaparken ders kitabından yararlanırım. \\
\hline & 40 & Sınavlara hazırlanırken ders ve çalışma kitaplarından yararlanırım. \\
\hline & 39 & Derste anlamadığım bir konuyu, ders kitabından çalışarak anla: \\
\hline \multirow{7}{*}{ 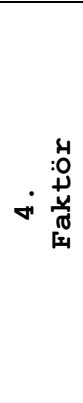 } & Md. & Matematik dersinin işlenişi \\
\hline & 9 & $\begin{array}{l}\text { Bir konuyu etkinliklerle işlemek yerine, öğretmenimin anlatması o } \\
\text { konuyu daha iyi anlamamı sağlar. }\end{array}$ \\
\hline & 17 & $\begin{array}{l}\text { Ders ve çalışma kitaplarının yanı sıra başka kaynak kitaplardan da } \\
\text { faydalanırım. }\end{array}$ \\
\hline & 4 & $\begin{array}{l}\text { Öğretmenimin bir problemi farklı yöntemlerle çözmesi problem çözümünü } \\
\text { daha iyi anlamama yardımcı olur. }\end{array}$ \\
\hline & 18 & Öğretmenimizin verdiği görevler (ödevler) dersi anlamama yardımcı olur. \\
\hline & 27 & $\begin{array}{l}\text { Daha önce karşılaşmadığımız bir problem durumunda, problemi ilk önce } \\
\text { öğretmenimiz çözer. }\end{array}$ \\
\hline & 28 & Öğretmenimiz, bir problemi farklı yöntemlerle çözmeye özen gösterir. \\
\hline \multirow{7}{*}{ ம } & Md. & Sınıfta matematiksel düşünme ve iletişime verilen önem \\
\hline & 29 & $\begin{array}{l}\text { Öğretmenimiz derste, birden fazla doğru yanıtı olabilecek sorular } \\
\text { sorar. }\end{array}$ \\
\hline & 31 & Öğretmenimiz derste matematiksel tartışmalara yer verir. \\
\hline & 26 & Öğretmenimiz işlediğimiz konularla ilgili problemler kurmamızı ister. \\
\hline & 23 & Öğretmenimiz matematik dersinde "Neden? / Niçin?" soruları sorar. \\
\hline & 20 & $\begin{array}{l}\text { Daha önce öğrenmediğimiz bir problemle karşılaştığımızda, öğretmenimiz } \\
\text { problemi arkadaşlarımızdan destek alarak çözmemizi bekler. }\end{array}$ \\
\hline & 30 & $\begin{array}{l}\text { Öğretmenimiz bir problemi daha iyi incelememizi sağlayacak sorular } \\
\text { sorar. }\end{array}$ \\
\hline
\end{tabular}

Hesaplamalar sonucunda beş faktörden oluşan 30 maddelik ölçeğin maddeleri Tablo 2'de verilmiştir. Tabloda görüldüğü gibi öğrencilerin matematik ders kitapları hakkındaki görüşlerinden oluşan birinci faktör dokuz maddeden (1, 3, 5, 6, 8, 11, 12, 13 ve 14) oluşmaktadır. İkinci faktör olan öğrencinin matematiksel düşünme düzeyi dört madde 
ile (19, 25, 36 ve 37) ölçülmektedir. Beş maddeden (32, 33, 38, 39 ve 40) oluşan üçüncü faktör matematik dersinde kitap kullanımına yöneliktir. Dördüncü faktör matematik dersinin işlenişini altı madde (4, 9, 17, 18, 27 ve 28) ile ölçerken beşinci faktör olan sınıfta matematiksel düşünme ve iletişime verilen önem de altı madde (20, 23, $26,29,30$ ve 31) ile ölçülmektedir.

\section{TARTIŞMA VE SONUÇ (DISCUSSION AND CONCLUSION)}

Araştırmada, matematik dersinin ve Milli Eğitim Bakanlığı tarafından onaylanan matematik kitaplarının öğrenci açısından değerlendirilebilmesi amacıyla bir ölçek oluşturulmuştur. Ölçekten elde edilen verilerin, ilk aşamada örneklem grubuna uygunluğu Kaiser Meyer Olkin (KMO) ve Bartlett Küresellik testleri ile kontrol edilmiştir. KMO değeri 0,905 ve $\chi^{2}=10485,487$ ( $\mathrm{p}=0,000$ ) bulunmuştur. Toplam 30 maddeden oluşan Likert tipi ölçeğin yapı geçerliliğini belirlemek için asal eksenlere göre döndürülmüş (varimax-rotated) temel bileşenler yöntemi kullanılarak yapılan faktör analizi sonunda her bir maddenin öz değerleri ve faktör yükleri hesaplanmıştır. Ölçekte yer alan her bir maddenin faktör yükünün 0,400'den büyük olmasına dikkat edilmiştir. Ayrıca ölçeğin her maddesi için alt \%27 ve üst \%27'lik grupların ortalamaları arasındaki farklara bakılarak, her bir maddenin ayırt edici özelliğe $(p<0,001)$ sahip olduğu belirlenmiştir. Doğrulayıcı faktör analizi ile hesaplanan uyum indeksleri kabul edilebilir sınırlar içerisinde bulunduğundan elde edilen ölçek yapı geçerliliğini sağlamıştır.

Beş faktörden oluşan ölçme aracının Cronbach Alfa katsayısı hesaplanmış ve 0,852 olarak bulunmuştur. Alt faktörler: öğrencinin matematik ders kitapları hakkındaki görüşleri, öğrencinin matematiksel düşünme düzeyi, matematik dersinde kitap kullanımı, öğretmenin matematik dersini işleyişi ve öğretmenin matematiksel düşünce ve iletişime verdiği önem olarak adlandırılmıştır.

Araştırmada geliştirilen ölçeğin, 6., 7. ve 8. sınıf öğrencilerinin matematik dersi, dersin işlenişi, bu programda kendilerinin matematiksel düşünce düzeyinde ne derece etkin oldukları ve ders kitapları hakkındaki görüşlerini belirlemek için kullanılmaya uygun olduğu sonucuna ulaşılmıştır. Geçerli ve güvenilir olduğu bulunan ölçeğin, matematik programının önemsediği matematiksel iletişim, akıl yürütme, ilişkilendirme, problem çözme becerilerine yönelik öğrenci görüşlerini yansıttığı ve programın geliştirilmesine yardımcı olacă̆ı düşünülmektedir.

\section{KAYNAKLAR (REFERENCES)}

- Altun, M. ve Arslan, Ç., (2006). İlköğretim Öğrencilerinin Problem Çözme Stratejilerini Öğrenmeleri Üzerine Bir Çalışma. Uludağ Üniversitesi Eğitim Fakültesi Dergisi 19 (1), 1-21.

- Apple, M.W., (1986). Teachers and Texts: A Political Economy of Class and Gender Relations in Education. New York: Routledge \& Kegan.

- Aşkar, P., (1986). Matematik Dersine Yönelik Tutumu Ölçen Likert Tipi Bir Ölçeğin Geliştirilmesi. Eğitim ve Bilim, 11(62), 3136 .

- Bal, A.P. ve Artut, D., (2013). The Evalution of the Elementary Mathematics Curriculum. International Journal of Social Science, $6(8), 805-812$.

- Barr, R., (1988). Conditions Influencing Content Taught Nine Fourth-Grade Mathematics Classrooms. Elementary School Journal, 88, 387-411. 
Güner, N., Akkurt Denizli, Z., Sezer, R. ve Bayraktar, A. NWSA-Education Sciences, 1C0632, 10, (2), 54-65.

- Büyüköztürk, Ş., (2010). Sosyal Bilimler İçin Veri Analizi El Kitabı. Ankara: Pegem Akademi.

- Cai, J., (2003). Singaporean Students' Mathematical Thinking in Problem Solving and Problem Posing: An Exploratory Study. International Journal of Mathematics Education in Science and Technology, 34(5), 719-737.

- Castro Superfine, A., (2008). Planning for Mathematics Instruction: A Model of Experienced Teachers' Planning Processes in the Context of a Reform Mathematics Curriculum. The Mathematics Educator, $18(2), 11-22$.

- Cohen, L., Manion, L., and Morrisson, K., (2008). Research Methods in Education. New York: Routledge.

- Çakır, İ., (2009). İlköğretim Beşinci Sınıf Matematik Ders Kitaplarının Öğretmen ve Öğrenci Görüşleri Doğrultusunda Değerlendirilmesi. Yayımlanmamış Yüksek Lisans Tezi, Çukurova Üniversitesi Sosyal Bilimler Enstitüsü, Adana.

- da Ponte, J.P., (2012). A Practice-Oriented Professional Development Programme to Support the Introduction of a New Mathematics Curriculum in Portugal. Mathematics Teacher Education, 15, 317-327.

- Dayak, E., (1998). İlköğretim 5. Sınıf Matematik Ders Kitaplarının Eğitim-Öğretime Uygunluğunun Değerlendirilmesi. Yayınlanmamış Yüksek Lisans Tezi. Marmara Üniversitesi Eğitim Bilimleri Enstitüsü.

- Demircioğlu, H., (2009). İlköğretim Matematik Programının Uygulamadaki Etkinliklerinin Öğrenci Görüşleri Açısından Incelenmesi. Yayınlanmamış Yüksek Lisans Tezi. İstanbul Üniversitesi Sosyal Bilimler Enstitüsü.

- Erkuş, A., (2012). Psikolojide Ölçme ve Ölçek Geliştirme. Ankara: Pegem Akademi.

- Fan, L. and Zhu, Y., (2000). Problem Solving in Singaporean Secondary Mathematics Textbooks. The Mathematics Educator, $5(1 / 2), 117-141$.

- Freeman, D.J. and Schmidt, W.H., (1982). Textbooks: Their Messages and Their Effects. American New York: Educational Research Association.

- Graybeal, S.S., (1988). A Study of Instructional Suggestions in Fifth-Grade Mathematics and Social Studies Teacher's Guides and Textbooks. Unpublished Doctoral Dissertation, University of Chicago.

- Haggarty, L. and Pepin, B., (2002). An Investigation of Mathematics Textbooks and Their Use in English, French and German Classrooms: Who Gets an Opportunity to Learn What? British Educational Research Journal, $28(4)$, 567-590.

- Hirsch, C.R., and Reys, B.J., (2009). Mathematics Curriculum: A Vehicle for School Improvement. Mathematics Education, 41, 749761 .

- Jackson, P.W., (1992). Conceptions of Curriculum and Curriculum Specialists. In P.W. Jackson (Ed.) Handbook of Research on Curriculum, (pp. 3-40). New York: Macmillan.

- Kalaycı, Ş., (2008). SPSS uygulamalı çok değişkenli istatistik teknikleri. Ankara: Asil Yayın Dağıtım Ltd. Şti.

- Karakelleoğlu, S., (2007). İlköğretim 4.Sınıf Matematik Ders Kitaplarına İlişkin Öğretmen, Öğrenci ve Uzman Görüşleri. Yayınlanmamış Yüksek Lisans Tezi, Balıkesir Üniversitesi. 
- Karasar, N., (2012). Bilimsel Araştırma Yöntemleri. Ankara: Nobel.

- Kargar, M., Tarmizi, R.A., and Bayat, S., (2010). Relationship Between Mathematical Thinking, Mathematics Anxiety and Mathematics Attitudes Among University Students. Procedia-Social and Behavioral Sciences, 8, 537-542.

- Kline, R.B., (2011). Principles and Practice of Structural Equation Modeling. New York: The Guilford Press.

- Krammer, H.P.M., (1985). The Textbooks as Classroom Context Variable. Teaching and Teacher Education, 1(4), 273-278.

- Li, Y., Chen, X., and An, S., (2009). Conceptualizing and Organizing Content for Teaching and Learning in Selected Chinese, Japanese and U.S. Mathematics Textbooks. ZDM Mathematics Education, 41, 809-826.

- Lipnevich, A.A., MacCann, C., Krumm, S., Burrus, J., and Roberts, R.D., (2011). Mathematics Attitudes and Mathematics Outcomes of U.S. and Belarusian Middle School Students. Journal of Educational Psychology, 103(1), 105-118.

- Marchis, I., (2011). Factors that Influence Secondary School Students' Attitude to Mathematics. Procedia-Social and Behavioral Sciences, 29, 786-793.

- Papanastasiou, C., (2000). Effects of Attitudes and Beliefs on Mathematics Achievement. Studies in Educational Evaluation, 26, 27-42.

- Remillard, J.T., (2000). Can Curriculum Materials Support Teachers' Learning? Elementary School Journal, $100(4), 331-350$.

- Reys, B., Lappan, G., and Hirsch, C., (2003). Center for the Study of Mathematics Curriculum. Retrieved from http://mathcurriculumcenter. org/crq.htm

- Reys, B., Reys, R., and Chavez, O., (2004). Why Mathematics Textbooks Matter. Educational Leadership, 61(5), 61-66.

- Schmidt, W.H., McKnight, C.C., and Raizen, S.A., (1997). A Splintered Vision: An Investigation of U.S. Science and Mathematics Education. Dordrecht, The Netherlands: Kluwer.

- Shiyyab, M., el-Hersh, A., and Mufleh, M., (2010). Understanding Students' Attitudes to Use Dynamic Models for Learning Mathematics. Procedia-Social and Behavioral Sciences, 5, 22822289.

- Sosniak, L.A. and Stodolsky, S.S., (1993). Teachers and Textbooks: Materials Use in Four Fourth-Grade Classrooms. The Elementary School Journal, 93(3), 249-275.

- Soycan, S.B., (2006). 2005 Yılı İlköğretim 5. Sınıf Matematik Programının Değerlendirilmesi. Yayınlanmamış Yüksek Lisans Tezi. Uludağ Üniversitesi, Sosyal Bilimler Enstitüsü, Bursa.

- Şimşek, Ö.F., (2007). Yapısal Eşitlik Modellemesine Giriş. Temel İlkeler ve LISREL Uygulamaları. Ankara: Ekinoks.

- Tabachnick, B.G. and Fidell, L.S., (2012). Using Multivariate Statistics. New Jersey: Pearson.

- Talmage, H., (1972). The Textbook as Arbiter of Curriculum and Instruction. Elementary School Journal, 73, 20-25.

- Taşdemir, C., (2009). İlköğretim İkinci Kademe Öğrencilerinin Matematik Dersine Karşı Tutumları: Bitlis İli Örneği. Dicle Üniversitesi Ziya Gökalp Eğitim Fakültesi Dergisi, 12, 89-96. 
- Turanlı, N., Karakaş Türker, N. ve Keçeli, V., (2008). Matematik Alan Derslerine Yönelik Tutum Ölçeği Geliştirilmesi. Hacettepe Üniversitesi Eğitim Fakültesi Dergisi, 34, 254-262.

- Tyson, H. and Woodward, A., (1989). Why Students Aren't Learning Very Much from Textbooks. Educational Leadership, 47(3), 14-17.

- Tyson, H. and Bernstein, H., (1988). A Conspiracy of Good Intentions: America's TEXTBOOK FIASCO. Washington DC: Council for Basic Education.

- Uşun, S. and Gökçen, E., (2010). The Effect of Activity Based Instruction Approach on Students' Attitudes towards the Mathematics Lesson in the Second Grade of Primary School. International Online Journal of Educational Sciences, 2(2), 532561.

- Valverde, G.A., Bianchi, L.J., Wolfe, R.G., Schmidt, W.H., and Houang, R.T., (2002). According to the Book: Using TIMSS to Investigate the Translation of Policy into Practice through the World of Textbook. Boston: Kluwer Academic Publishers.

- Wong, N., Lam, C., Sun, X., and Yan Chan, A.M., (2008). From "Exploring the Middle Zone" to "Constructing a Bridge": Experimenting in the Spiral Bianshi Mathematics Curriculum. International Journal of Science and Mathematics Education, 7, 363-382.

- Woodward, A. and Elliott, D.L., (1990). Textbooks: Consensus and Controversy. Chicago: National Society for the study of Education.

- Yenilmez, K., (2010). Ortaöğretim Öğrencilerinin Matematik Dersine Yönelik Umutsuzluk Düzeyleri. Hacettepe Üniversitesi Eğitim Fakültesi Dergisi,38, 307-317.

- Yılmaz, T., (2006). Yenilenen 5. Sınıf Matematik Programı Hakkında Öğretmen Görüşleri (Sakarya İli Örneği). Yayınlanmamış Yüksek Lisans Tezi, Sakarya Üniversitesi, Sosyal Bilimler Enstitüsü, Sakarya.

- Yüksel, E., (2010). İlköğretim 6. Sınıf Matematik Ders Kitaplarının Öğretmen ve Öğrenci Görüşleri Doğrultusunda Değerlendirilmesi. Yayınlanmamış Yüksek Lisans Tezi. Çukurova Üniversitesi, Eğitim Bilimleri Enstitüsü. Adana. 